\title{
LEGAL PRINCIPLES OF COUNTERACTING CYBERBULLYING AGAINST CHILDREN
}

\author{
IRYNA KHOMYSHYN
}

Educational and Scientific Institute of Law

Psychology and Innovative Education

of Lviv Polytechnic National University

12 Stepan Bandera St., Lviv, 79000 Ukraine

E-mail address: khomyshyni@gmail.com

ORCID: https://orcid.org/0000-0002-6180-3478

\section{ULIANA PARPAN}

Educational and Scientific Institute of Law

Psychology and Innovative Education

of Lviv Polytechnic National University

12 Stepan Bandera St., Lviv, 79000 Ukraine

E-mail address: uparpan35@gmail.com

ORCID: https://orcid.org/0000-0002-5082-0109

\section{NATALIIA LESKO}

Educational and Scientific Institute of Law Psychology and Innovative Education of Lviv Polytechnic National University

12 Stepan Bandera St., Lviv, 79000 Ukraine

E-mail address: leskonataly@gmail.com

ORCID: https://orcid.org/0000-0002-1790-8432

\section{MARIIA SLYVKA}

Educational and Scientific Institute of Law

Psychology and Innovative Education

of Lviv Polytechnic National University

12 Stepan Bandera St., Lviv, 79000 Ukraine

E-mail address: selena_18@ukr.net

ORCID: https://orcid.org/0000-0003-2679-1632

\section{MARYANA TSVOK}

Educational and Scientific Institute of Law

Psychology and Innovative Education 


\author{
of Lviv Polytechnic National University \\ 12 Stepan Bandera St., Lviv, 79000 Ukraine \\ E-mail address: maryana.kharysh@gmail.com \\ ORCID: https://orcid.org/0000-0001-7216-4002
}

\begin{abstract}
Goal. The essay explores the legal basis for combatting cyberbullying against children in the age of information technologies. The key signs of cyberbullying against children include the lack of time and geographical limits, the large scale and speed of sharing abusive information, and the unlimited audiences.

Methods. To achieve this goal, an empirical study was carried out, in which 180 first-year students (aged 17 years) who study at the Educational and Scientific Institute of Law, Psychology and Innovative Education of Lviv Polytechnic National University, took part. When studying the theoretical and methodological aspects of this research problem, the following theoretical methods were employed: analysis, synthesis, generalisation of data from psychological, pedagogical, scientific and methodological literature sources.

Results. The phenomenon of cyberbullying against children is present in many developed countries. The research showed that children generally are well informed about the possibilities of protecting their rights in case of cyberbullying. However, the legal basis for protecting victims of cyberbullying requires the adoption of several laws.

Conclusions. Most digital rights are enshrined in various UN Human Rights Resolutions that require systematisation into the single codified act - The Declaration of Digital Human Rights. The need for this act is increasingly growing. In ten years, it would be difficult to think of a model democratic society. To build a legal basis in the area of e-democracy in line with international standards, it is important to adopt the laws on protection of freedom on the Internet," and on e-democracy, which will certainly secure digital rights of children.

Key words: cyberbullying, bullying, cyber-violence, Internet, information technology
\end{abstract}

\title{
INTRODUCTION
}

$\mathrm{T}$ he defining feature of the modern information society is that it recognises the priority of information as one of the results of human activity. Nowadays, people who spend most of their time with computers can no longer imagine their existence without them, which often leads to computer addiction. Besides, the problem of cyberbullying has also arisen in the era of information technology: bullying a person through the Internet, via messages containing insults or intimidation. Such mobbing or harassment can be directed toward either an adult or a child. Currently, the phenomenon of cyberbullying is actively manifested in many developed foreign countries, such as the United States, Canada, the countries of the European Union and other states, where government agencies are forced to pay more and more attention to this issue. 


\section{MAJOR WARNING SIGNS OF CYBERBULLYING AGAINST CHILDREN}

Experts identify many variants of violent and illegal behaviour on the Internet:

- roasting, or flaming - the exchange of short angry and offensive remarks between two or more participants using communication technologies. It mostly unfolds in "public" space on the Internet, in chat rooms, forums, in discussion groups, and sometimes turns into a protracted war;

- abuse, constant tiresome attacks - most often they consist of repeated abusive messages aimed at the victim (for example, hundreds of text messages sent to a cell phone, constant calls);

- slander, defamation - dissemination of false derogatory information using computer technology. These can be text messages, photos, and songs that portray the victim in a harmful, sometimes sexual manner;

- deception, luring confidential information and its dissemination - obtaining personal information in interpersonal communication and transferring it (texts, photos, videos) to the public Internet area or by mail to those for whom it was not intended;

- alienation, isolation - in a virtual environment, expulsion can also cause severe emotional distress, up to complete emotional destruction of the child. Online alienation is possible in any type of environment where password protection is used, a junk mailing list or a friends list is created;

- cyber-harassment is an act of covert surveillance of the pursued person and those loitering around, usually carried out anonymously in order to organise illegal activities. By tracking careless and unwary users via the Internet, the offender receives information about the time, place and all the necessary conditions for a future attack;

- "happy slapping" - videos of attacks with the purpose of sexual assault or its imitation. These videos posted on the Internet can be viewed by thousands of people, usually without the victim's consent (Naidionova, 2011).

Statistics show that a third of British teenagers have become victims of cyberbullying, and female representatives are 4 times more likely to be victims of this misconduct than boys. However, studies by EU commissioners provide slightly different statistics. For example, in Germany every fifth child suffers from abuse on the Internet, in Poland - every third child, while in the UK every second child (Stoyetskyi, 2013).

Certain researchers argue (Naidionova, 2012) that adolescent victims of cyberbullying are 1.9 times more likely to commit suicide. Thus, the transformational processes of a globalising society have led to a new social phenomenon - cyber-suicide, i.e. suicide directly or indirectly related to online aggression. The qualification (determination of the nature) of such an offense is contained in Art. 120 of the Criminal Code of Ukraine, which states that driving a person into suicide or attempted suicide is the result of cruel treat- 
ment, blackmail, coercion to unlawful actions or systematic humiliation of his/ her human dignity. Systematic humiliation of human dignity consists, in particular, in repeated insults, mockery of the victim, bullying and harassment, dissemination of slanderous (defamatory) fabrications, and other forms of degrading treatment of the victim. The legislator does not specify how these actions can be carried out. We would like to note that Part 3 of Art. 120 of the Criminal Code of Ukraine determines that the above act is punishable by 7 to 10 years' imprisonment when committed against a minor (Criminal Code of Ukraine, 2001).

It should be emphasised that in addition to cyberbullying, other negative acts on the Internet are singled out in scientific circles. In particular, fitting - using Internet technology to gain access to confidential information about users (passwords, logins, financial information, etc.); grooming - using Internet technology by offenders to ingratiate themselves with the child in order to predispose him/her to some inappropriate (specifically - sexual) behaviour.

An analysis of the domestic administrative legislation allows us to conclude that there is no article providing for administrative liability for committing cyber-hooliganism. Art. 173 of the Code of Ukraine on Administrative Offenses provides for liability only for petty hooliganism, like obscene swearing in public places, insulting abuse of citizens and other similar actions that breach the public peace and good order (Code of Ukraine on Administrative Offenses, 1984). Even a brief overview of the above-mentioned misdemeanour allows us to conclude that cyber-hooliganism does not fall under the signs of petty hooliganism. Because the object of this offense is public relations in the field of public order and in general the objective element is characterised by various forms (Stoyetskyi, 2013).

The International Telecommunication Union (ITU), together with partner organisations from various industries, civil society representatives, government agencies, UN agencies and other stakeholders, made efforts to protect children from cyber-violence and exploitation: in 2009, it published "Guidelines on Child Online Protection" for children, parents, IT companies and government agencies, and in November 2010, together with partners, it launched the global "Child Online Protection (COP) Initiative". Within this program, it is planned to: adopt "codes of ethics" for various industries, organise national hotlines, conduct public awareness campaigns, create methodological materials on legislation, and conduct trainings for parents, guardians and educators.

There is a wide range of interpretations of the concept of cyberbullying in the scientific literature, i.a.:

- aggressive behaviour of a certain person, often a teenager, which is carried out against a specific child (victim) by the means of electronic communication (the Internet, mobile phones, social networks) (Fadieyeva, 2013);

- a new form of aggression, which involves cruel actions with the aim of annoying, harming, humiliating a person using information and communication tools: mobile phones, e-mail, social networks, etc. (Naidionova, 2011). 
Lubenets proposes to define violence in the information space or cyberviolence (cyberbullying) as intentional, indirect, usually systematic, unlawful acts on the part of a student(s) of educational institutions, directed against (an) other student(s) against his/her (their) will, committed with the use of information and communication means and expressed in the form of transferring messages, photos, video materials, video recordings to this (these) student(s) and/or an indefinite circle of other persons in order to defame, humiliate, intimidate, insult, harass him/her (them), resulting in a violation of rights to safe learning environment and information, privacy, respect, honour, dignity, property, health or life, and causing physical, mental, moral harm to this (these) student(s) (Lubenets, 2017).

Cyberbullying can take two main forms: personalised, which involves direct mailing of information to the victim, and non-personalised, which involves disseminating information about the victim and sharing it in the public information space with an indefinite circle of people, creating a negative environment of disrespect, humiliation, condemnation, isolation and the like around the victim in their peer social groups (in a "relational tribe": class, neighbourhood, school). The second form of cyberbullying is much more dangerous in the social terms.

Despite this, cyberbullying is characterised by the highest level of secrecy compared to all other types of violence.

The differences between cyberbullying and other types of school violence that make it even more dangerous are:

- lack of temporal and geographical restrictions. That is, the victim cannot hide from this type of harassment (even at home outside of school hours). The cyber-stalker has round-the-clock, constant access to the victim through modern technical tools (e-mail, mobile communication, social network profile, etc.);

- large scale and high speed of dissemination of offensive information as well as a virtually unlimited audience: it is much wider than with regular school bullying;

- protection of the persecutors by the virtual world, that is, their anonymity, which gives the cyber-bullies confidence in the impunity of their actions, while for the victim, on the contrary, creates insecurity, constant anxiety and fear in anticipation of further acts of persecution and harassment;

- high level of latency of this type of violence, which causes difficulties in detecting and combating it;

- gaps in the legislation on liability for the above acts. The resulting impunity breeds audacity on the part of cyber-hooligans (Lubenets, 2017).

In order to study the phenomenon of cyberbullying against children, a survey was conducted in 2021 among 180 children (aged 17), i.e. first-year students studying at the Educational and Scientific Institute of Law, Psychology and Innovative Education of Lviv Polytechnic National University. 
To the question "Do you think the problem of cyberbullying against children is relevant and requires in-depth analysis?" 92\% of the respondents answered "yes," $4 \%$ - "no," and 4\% - "yes, but there are more pressing problems."

To the question "Do you agree with the statement that under today's conditions in Ukraine the legal protection of children from cyberbullying is insufficient and urgently needs improvement?" 92\% responded in the affirmative, $8 \%$ responded in the negative, and $0 \%$ gave their own answer.

In answers to the question "Who/what do you think should be the main link in the prevention of cyberbullying against children?" the following results were obtained: territorial bodies of the National Police - 21\%; Ministry of Social Policy - $28 \%$; public organisations - $40 \%$; education management bodies, educational institutions, establishments and organisations of the educational system $-10 \%$.

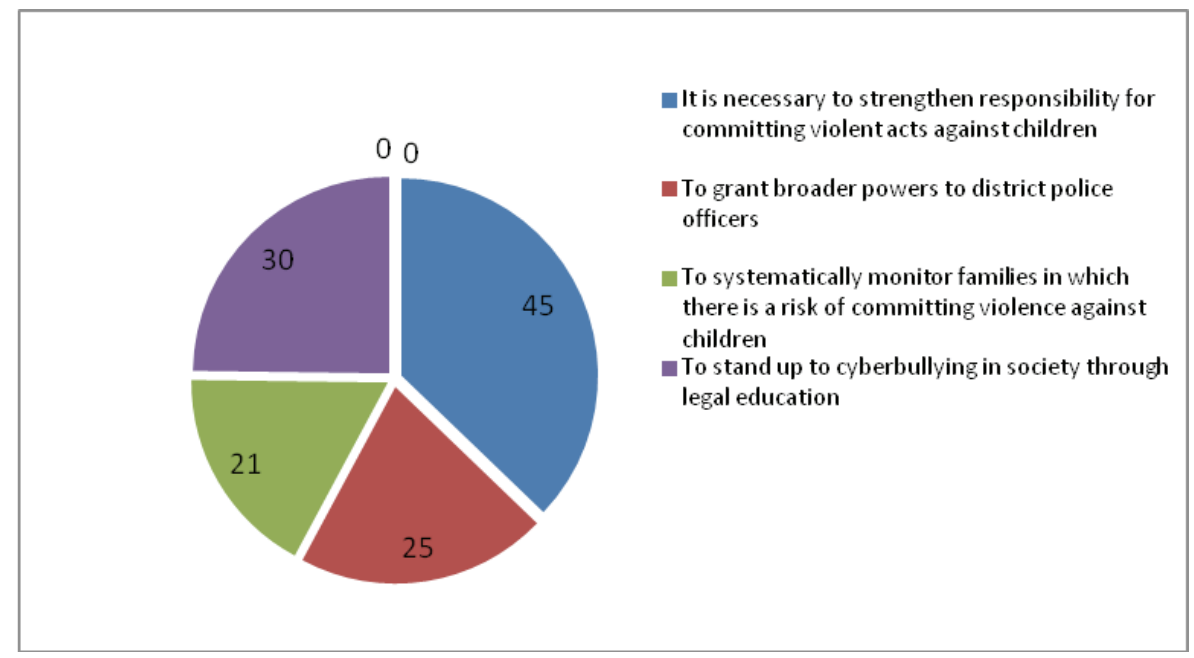

Question "How, in your opinion, can we reduce the level of cyberbullying against children in the educational environment?"

The study has shown that children are generally informed about possible ways to protect their rights in the event of cyberbullying.

\section{COMBATING CYBERBULLYING AGAINST CHILDREN IN UKRAINE}

In order to prove the existence of violence against children on the Internet, victims provided screenshots as evidence. However, according to par. 46 of the Resolution of the Plenum of the Supreme Economic Court of Ukraine "On Certain Issues of the Practice for the Settlement of Disputes Related to the Protection of Intellectual Property Rights" dated October 17, 2012, No. 12, printouts of web pages alone cannot serve as evidence in the case (On Certain Issues of 
the Practice for the Settlement of Disputes Related to the Protection of Intellectual Property Rights: Resolution of the Plenum of the Supreme Economic Court of Ukraine, 2012).

Informational violence against a child includes any deliberate psychological actions of one of the subjects of information relations towards the child, which violate his/her constitutional rights and freedoms as a person and a citizen and/or harm his/her psychophysical health or moral and psychological state. Psychological abuse of a child means violence associated with the action of the subject of information relations against the child through verbal abuse or threats, harassment, intimidation, including the use of information and communication technologies, which deliberately cause emotional insecurity, inability to protect oneself, and (potentially) harm mental health (Radziyevska, 2018).

In fact, this feature - the ability to be quickly duplicated and of mass character - accelerates the spread of information affecting the interests of the child on the Internet. The inability of children to understand these complex technologies leads them to believe that this (a negative post about them, photos, rumours) is: a) permanent; b) their behaviour is condemned (ridiculed) by a huge group of people. Such a feature as the presence of a wide audience fundamentally changes the concept of "consistency" (systemic nature) when it comes to online violence. While in reality violence must be repetitive in order to become a systemic phenomenon, the systemic nature of cyberbullying is already provided for by the presence of a wide audience, which, by targeting one negative message, gives it systematicity through reposts and likes. While in real life, the persecutor must perform several actions against the victim to cause harm, in cyberspace one action is enough, provided that it is repeated (disseminated, reposted or supported) by others.

Secondly, cyberbullying is difficult to pinpoint. The peculiarity of cyberbullying is that it has unlimited time and space. If a child can territorially protect him or herself from school violence at home, then online violence does not provide for such a possibility.

Thirdly, anonymity another feature of online violence is. Cyberbullying may involve a stalker who is difficult to identify, which points to two characteristics:

- the ability to carry out psychological violence (abuse) while "hiding" behind an anonymous account. This leads to the fact that anyone can be the initiator of cyberbullying, regardless of who he/she is in real life;

- the victim's inability to respond to the harassment in real life due to a lack of understanding as to who is actually harassing, persecuting him/her. This leads to a constant sense of danger and to the formation of paranoid moods (Stop School Terror, 2017).

Cyberbullying has many features of conventional bullying; moreover, it can be used as part of it. It does not matter where the pressure on the child began: online or in reality. Both virtual and real life can complement each other and aggravate the child's problem. 
Summing up, we would like to note that due to the lack of moral standards, even greater separation between parents and children, the inability to control and the low probability of being prosecuted, the blurring of the concepts of "victim" and "persecutor," the important role of social networks in adolescent life, cyberbullying can be considered an independent type of persecution, which will become even more widespread in the future (Stop School Terror, 2017).

A natural (instinctive) reaction of parents when detecting cases of abuse of their child on the Internet is to prohibit the use of the computer (to technically eliminate the threat). But any repressive actions (such as denying access to the Internet, seizing a mobile phone) can lead to the fact that the next time the child may not tell his/her parents that he/she is being bullied on the Internet. In addition, for today's children, denial of access to social networks is a greater punishment than being bullied.

Countering cyberbullying should involve working with the parents. After all, they are in the best position to be able to quickly identify that their child is being bullied online. This requires:

- improving computer literacy among parents. The inability of some parents to understand what is happening on the Internet leads to misunderstandings and their inability to give advice to the child;

- reducing the virtual information gap between the generations;

- parents registering in the social networks in which the child has an account;

- efforts to refocus the child to their flow of information. In particular, trying to ask him/her to find the information the parents need. In addition, it allows the child to understand the constructive possibilities provided by modern information technologies and appropriate use of those possibilities;

- understanding and discussing with the child the peculiarities of presenting (posting) information on the Web. In this context, it should be explained that any information that a child encounters on the Internet requires verification; today's information posted on social networks loses its relevance after a few days - this feature is important to remember so that the child understands that certain messages affecting his/her dignity will be irrelevant to Internet users in a short time;

- permanent monitoring of the online reputation of the child, class and school. It is a good idea to check back from time to time by simply reviewing the results on either Google or YouTube (searching for child's name, school number) (Stop School Terror, 2017).

It is important to teach the child about the possibilities of protecting private data - protecting personal data, preventing the sending of intimate photos, plastic card numbers and other private information, as well as about measures allowing for blocking or blacklisting unwanted messages. The child must understand that the transfer of any personal data is dangerous. 


\section{CONCLUSIONS}

In view of the above considerations, it is reasonable to criminalise publication and distribution on the Internet of the information containing child pornography. It is advisable that the Law of Ukraine "On Childhood Protection" prohibit the disclosure or publication in the media of confidential information about children in difficult circumstances, if the dissemination of such information may harm the child, regardless of the consent of the child's parents or other legal representatives. Media violence is a form of psychological violence, including the promotion of violent action through the media, if it causes the affected person to have emotional insecurity, inability to protect him- or herself, or if it harms mental health.

The human rights system will change depending on the conditions for their implementation. With the development of digital technologies, new digital rights are emerging, while the phenomenon of cyberbullying is actively manifested. Despite the existence of international legal enactments that regulate relations on the Internet and protect children's digital rights, in Ukraine this area remains unregulated at the legislative level. An important trend in addressing the problems associated with the use of the Internet is the adoption of laws "On the protection of freedom of expression on the Internet," "On e-democracy," as well as the introduction of annual monitoring of the status of enforcement of children's digital rights. The adoption of the above laws will contribute to the legal framework to ensure the functioning of e-democracy in line with international standards, and raise awareness of citizens as to using the e-democracy tools.

\section{REFERENCES}

[1] Code of Ukraine on Administrative Offenses of 07.12.1984 No. 8073-X, Bulletin of the Verkhovna Rada of Ukraine 1984, Addendum to No. 51.

[2] Fadieyeva, M. V. (2013). The structure of teacher's psychological readiness to provide psychological assistance to the child - cyberbully-victim. Problems of Modern Pedagogical Education. Series: Pedagogy and Psychology: A Collection of Articles, 39(1), 21-27.

[3] Child Rights International Network (2001). Five years on: A global update on violence against children. Retrieved July 18, 2021, from http://www.crin.org/en/docs/5-years-on-a-global-update-on-violence.pdf

[4] Lubenets, I. H. (2017). Violence among students of general education institutions: criminological characteristics and preventive measures [Unpublished thesis for a Candidate Degree in Law Sciences]. State Research Institute of the Ministry of Internal Affairs of Ukraine, Kyiv.

[5] Naidionova, L. A. (2011). Cyberbullying or aggression on the Internet: Identification methods and child protection: Instructional guidelines. Kyiv: Edition 4.

[6] Naidionova, L. A. (2012) Aggressive cyberspace or aggressive users? - psychological principles of overcoming cyber-bullying. Psychological Perspectives. Special Issue. Problems of Cyber-Aggression, 2, 83-92.

[7] On certain issues of the practice for the settlement of disputes related to the protection of intellectual property rights: Resolution of the plenum of the Supreme Economic Court of Ukraine dated October 17, 2012, No 12. Bulletin of Economic Judicial Proceedings, 6, 57.

[8] Radziyevska, O. H. (2018). Legal principles of counteracting the negative informational influences on children in Ukraine [Unpublished thesis for a Candidate Degree in Law Sciences]. Kyiv. 
[9] Ukrainian Institute for the Study of Extremism (2017). Stop school terror. Features of harassment in childhood. Prevention and counteraction to bullying. Retrieved from http://uire.org.ua/wp-content/uploads/2017/11/Doslidzhennya-buling.pdf.

[10] Stoyetskyi O. V. (2013). Administrative liability for offences in the field of information security of Ukraine [Unpublished thesis for a Candidate Degree in Law Sciences]. Zaporizhzhia.

[11] The Criminal Code of Ukraine of April 5.04.2001 No. 2341-III, Bulletin of the Verkhovna Rada of Ukraine 2001, 25-26. 